\title{
Making Hand sanitizer from Eucalyptus citriodora plants as an economic opportunity in the new normal era
}

\author{
M. Syafii ${ }^{1 *}$, Arif Rahman ${ }^{1}$, Hamdi $^{1}$, Sukma Hayati Hakim ${ }^{1}$, Muhammad Taufik ${ }^{2 *}$ \\ ${ }^{1}$ Prodi Ekonomi Pembangunan Fakultas Ekonomi, Universitas Sumatera Utara \\ ${ }^{2}$ Departemen Kimia Fakultas Matematika dan Ilmu Pengetahuan Alam, Universitas Sumatera \\ Utara
}

Email: syafiimuhammad91@gmail.com, Muhammad.taufik@usu.ac.id

\begin{abstract}
The Covid-19 pandemic that occurred in Indonesia, especially in Medan City, made people lose their jobs and had to survive to prevent the transmission of Covid-19. On average, residents who live close to infection-prone areas flock to buy masks and hand sanitizers. The supplies of hand sanitizers at various pharmacies has run out, even though the prices have gone up even ten times. This activity aims to socialize and train the making of hand sanitizers from Eucalyptus citriodora plants as an economic opportunity in the New Normal Era. The solution method is carried out by providing preparation training, extraction, and economic analysis of the availability of raw materials and the feasibility of Hand sanitizer products to the community in Tegal Sari Mandala II Village, Medan Denai District, Medan City. The results that have been achieved are hand sanitizer products made by the community and have high entrepreneurial skills in this New Normal Era. This activity is beneficial for the community, especially in terms of increasing knowledge and skills in making Hand sanitizers that can be applied to improve the economy during the Covid-19 Pandemic.
\end{abstract}

Keywords: New Normal, Hand sanitizer, Eucalyptus citriodora, extraction, economy.

\begin{abstract}
Abstrak
Pandemi Covid-19 yang terjadi di Indonesia khususnya di Kota Medan membuat masyarakat kehilangan pekerjaan dan harus bertahan hidup untuk mencegah penularan Covid-19. Rata-rata penduduk yang tinggal dekat dengan kawasan rawan penularan berbondong memborong masker dan hand sanitizer. Stok hand sanitizer di berbagai apotek habis, walaupun tersedia harganya sudah naik bahkan mencapai sepuluh kali lipat. Kegiatan ini bertujuan untuk sosialisasi dan pelatihan pembuatan Hand sanitizer dari Tanaman Eucalyptus citriodora sebagai Peluang Ekonomi di Era New Normal. Metode penyelesaian dilakukan dengan memberikan pelatihan pembuatan mulai dari preparasi, ekstraksi, dan analisa ekonomi keterdapatan bahan baku dan kelayakan produk Hand sanitizer kepada masyarakat di Kelurahan Tegal Sari Mandala II Kecamatan Medan Denai Kota Medan. Hasil yang telah dicapai adalah produk hand sanitizer yang dapat dibuat sendiri oleh masyarakat dan kemampuan masyarakat yang tinggi untuk berwirausaha di Era New Normal ini. Kegiatan ini bermanfaat bagi masyarakat terutama dalam hal meningkatkan pengetahuan dan keterampilan pembuatan Hand sanitizer yang dapat diaplikasikan dalam menambah ekonomi di masa Pandemi Covid-19.
\end{abstract}

Kata Kunci: New Normal, Hand sanitizer, Eucalyptus citriodora, ekstraksi, ekonomi. 


\section{PENDAhuluan}

Kesehatan merupakan aspek penting yang dapat mempengaruhi kualitas hidup setiap individu. Salah satu cara yang efektif untuk menjaga kesehatan tubuh adalah menjaga kebersihan, salah satunya adalah kebersihan tangan (Andre et al. 2016). Tangan merupakan salah satu anggota tubuh yang sangat berperan penting dalam beraktivitas sehari-hari dan pada saat beraktivitas tangan sering kali terkontaminasi dengan mikroorganisme karena tangan menjadi perantara masuknya mikroba ke saluran cerna (Xavier et al. 2006). Mencuci tangan merupakan langkah awal untuk menghindari berbagai jenis kuman penyebab penyakit infeksi tetapi langkah ini sering kali diabaikan ataupun terlewatkan begitu saja (Niken, Arman, and Morika 2020). Berbagai upaya dilakukan untuk mengurangi penyakit gangguan pencernaan yang disebabkan oleh mikroba mulai dari pencegahan hingga penggobatan. Salah satu upaya pencegahan yang dilakukan yaitu dengan penggunaan hand sanitizer (Narang 2018). Hand sanitizer umumnya mengandung Ethyl Alkohol $62 \%$, pelembut, dan pelembab (Dixit et al. 2014). Selain alkohol dan pelembut, hand sanitizer juga mengandung anti bakteri lain seperti tryclosan, gliserol, tannin, saponin dan agen antimikroba lainnya. Kandungan bahan aktif yang ada dalam hand sanitizer adalah alkohol yang memiliki efektivitas paling tinggi terhadap virus, bakteri, dan jamur juga tidak menimbulkan resistensi pada bakteri. Alkohol sendiri dapat membuat tangan menjadi kering, sehingga hand sanitizer harus dilengkapi dengan moisturizer dan emolient, yang menjaga tangan tetap lembut dan tidak menjadi kering, tidak seperti larutan alkohol murni yang dapat menyebabkan dehidrasi pada kulit (Narang 2018).

Sebagai upaya pencegahan terhadap penyakit infeksi seperti diare dan infeksi saluran pernafasan akut, maka diperlukan suatu cara yang praktis dengan menggunakan hand sanitizer sebagai pengganti cuci tangan pakai sabun (Dixit et al. 2014). Secara umum hand sanitizer mengandung alkohol $60-95 \%$, benzalkonium chloride, benzethonium chloride, chlorhexidine, gluconatee, chloroxylenolf, clofucarbang, hexachloropheneh, hexylresocarcinol, iodine (Erni et al. 2020). Salah satu bahan yang dapat dimanfaatkan sebagai antivirus yang digunakan sebagai bahan baku pembuatan hand sanitizer adalah minyak atsiri kulit dari minyak Eucalyptus citriodora (Acharya et al. 2020). Minyak Eucalyptus ini memiliki sifat anti jamur atau membasmi kuman dan merupakan komponen yang dibutuhkan untuk menghambat bakteri patogen anti mikroba (Ghasemian 2018). Senyawa kimia yang terdapat dalam Eucalyptus citriodora adalah 1,8 Sineol dapat dimanfaatkan sebagai bahan baku hand sanitizer (Hayat and Munnawar 2017).

Hand sanitizer dapat digunakan sebagai pengganti sabun untuk cuci tangan dengan alas an praktis dan mudah digunakan (Xavier et al. 2006). Penggunaan bahan alami juga sangat membantu dalam penggunaan bahan baku yang mudah diperoleh untuk menghasilkan hand sanitizer yang optimal dan kualitas baik (Andre et al. 2016). Penggunaan hand sanitizer sebaiknya menggunakan proses edukasi kepada masyarakat terutama di masa pandemic. Hal ini sangat membantu dalam proses pencegahan Virus Covid-19 di Indonesia (Fatmawati 2020).

Minyak Eucalyptus memiliki khasiat sebagai anti virus dan masih terus diteliti terutama di era pandemi. Pada kegiatan ini, pengambilan Daun Eucalyptus sebagai bahan baku Hand sanitizer diambil dari Kawasan Padang Bulan Medan seperti pada Gambar 1.1. berikut ini :

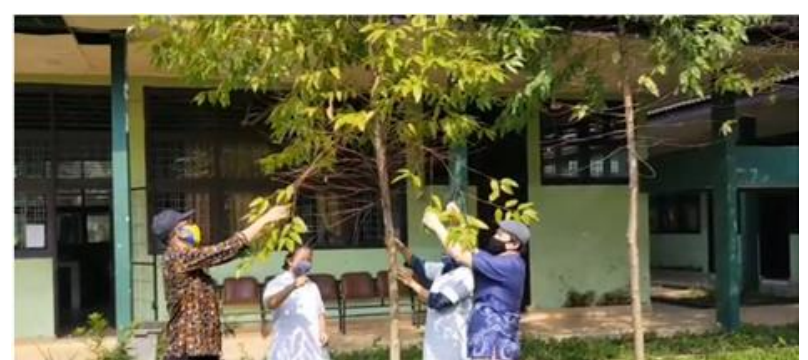


Gambar 1.1. Proses Pengambilan daun Eucalyptus

Gambar 1.1. menunjukkan proses pengambilan daun Eucalyptus di Kawasan Padang Bulan Medan. Minyak Eucalyptus yang ditemukan dalam Perdagangan, digolongkan menjadi tiga golongan utama - yaitu golongan minyak medisinal, industri, dan golongan minyak parfum (Alfian et al. 2019). Minyak Eucalyptus digunakan umumnya untuk tujuan pengobatan (Ghasemian 2018). Minyak Eucalyptus yang kaya akan sineol dan bebas dari fellandren, dijual dalam pertokoan untuk tujuan penggunaan dalam negeri. Minyak ini digunakan untuk minyak gosok, untuk diisap (inhalasi) (khususnya dengan penambahan sedikit kristal mentol), sebagai vermifusi, pembersih pakaian, penghapus noda dan lain sebagainya. Untuk Bidang Apikultur dibanyak daerah bunga Eucalyptus citriodora memberikan pakan hama yang signifikan untuk produksi lebah dan madu. Selain itu Eucalyptus citriodora banyak digunakan sebagai kayu bakar dan arang. Kayu Eucalyptus citriodora digunakan untuk kayu Pulp (Han Roliadi, Dulsalam 2010).

Pandemi covid-19 telah membatasi aktivitas masyarakat, hal ini berdampak pada penurunan aktivitas bisnis kemudian berimbas pada perekonomian (He, Deng, and Li 2020). Berdasarkan Laporan Badan Pusat Statistik (BPS) Agustus ini menyebut bahwa pertumbuhan ekonomi Indonesia pada kuartal II 2020 minus 5,32 persen. Sebelumnya, pada kuartal I 2020, BPS melaporkan bahwa pertumbuhan ekonomi Indonesia hanya tumbuh sebesar 2,97 persen, turun jauh dari pertumbuhan sebesar 5,02 persen pada periode yang sama 2019 lalu. Terjadinya kesenjangan antara target dan realisasi pertumbuhan ekonomi tentunya berdampak pada situasi ketenagakerjaan di Indonesia. Sektor tenaga kerja merupakan isu paling sensitif terdampak covid-19 karena banyaknya pengangguran baru yang muncul. Berdasarkan data Kementerian Ketenagakerjaan (Kemnaker) per 7 April 2020, akibat pandemi Covid-19, tercatat sebanyak 39.977 perusahaan di sektor formal yang memilih merumahkan, dan melakukan PHK terhadap pekerjanya. Total ada 1.010.579 orang pekerja yang terkena dampak ini. Rinciannya, 873.090 pekerja dari 17.224 perusahaan dirumahkan, sedangkan 137.489 pekerja di-PHK dari 22.753 perusahaan. Sementara itu, jumlah perusahaan dan tenaga kerja terdampak di sektor informal adalah sebanyak 34.453 perusahaan dan 189.452 orang pekerja. Agar tidak berdampak buruk terhadap perekonomian nasional diperlukan suatu terobosan untuk bisa memecahkan masalah ini. Salah satu solusi yang perlu dilakukan adalah dengan menggiatkan sektor-sektor informal yang bisa memanfaatkan potensi ekonomi pasca covid-19 (Praveen, Chowdary, and M 2020) (He, Deng, and Li 2020).

Kota medan adalah salah satu kota besar di indonesia yang terdampak terhadap covid19. Penurunan kinerja ekonomi tidak bisa dielakkan. Hal ini dapat dilihat dari terjadinya penurunan diberbagai sektor terutama sektor perdagangan yang mengalami penurunan pendapatan mencapai 80 persen, sementara itu terjadi juga penurunan tingkat hunia hotel yang cukup signifikan. Langkah-langkah yang dilakukan oleh pemerintah kota medan cukup beragam diantaranya dengan mengeluarkan peraturan wali kota medan nomor 11 tahun 2020 yang berisi aturan karantina kesehatan. Untuk membantu pemerintah kota medan dalam pemulihan ekonomi pasca covid19 maka diperlukan sejumlah program yang langsung berdampak pada masyarakat. Di kota medan banyak warganya yang telah kehilangan pekerjaan untuk menjaga kelangsungan hidup keluarga, maka diperlukan terobosan dimana masyarakat dapat terhindar dari covid19 dan dapat kembali menemukan potensi pekerjaan baru. Dalam mengakomodir terobosan tersebut kami mengadakan 
pengabdian masyarakat dengan tema pembuatan hand sanitizer sebagai peluang ekonomi baru dalam kondisi new normal/pasca covid-19.

Pengabdian Masyarakat ini bertujuan untuk sosialisasi dan pelatihan pembuatan Hand sanitizer dari Tanaman Eucalyptus citriodora sebagai Peluang Ekonomi di Era New Normal. Kegiatan ini bermanfaat bagi masyarakat terutama dalam hal meningkatkan pengetahuan dan keterampilan pembuatan Hand sanitizer yang dapat diaplikasikan dalam menambah ekonomi di masa Pandemi Covid-19.

\section{METODE PELAKSANAAN}

\subsection{Alat dan Bahan}

Alat yang digunakan adalah seperangkat alat destilasi, seperangkat alat pencampur bahan, dan pengaduk. Bahan yang digunakan adalah daun Eucalyptus citriodora, alkohol, glycerin, $\mathrm{H}_{2} \mathrm{O}_{2}$, dan aquadest.

\subsection{Lokasi Pengabdian Masyarakat}

Pengabdian Masyarakat dilaksanakan pada Kelurahan Tegal Sari Mandala II Kecamatan Medan Denai Kota Medan. Peta Lokasi dapat dilihat pada Gambar 2.1. berikut ini :

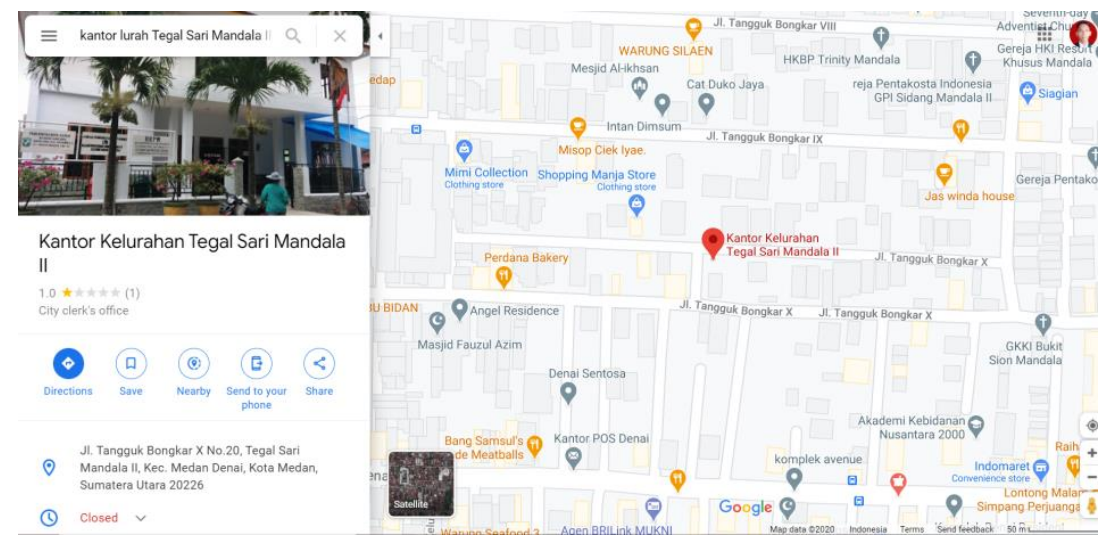

Gambar 2.1. Peta Lokasi Penelitian

Gambar 2.1. menunjukkan Peta lokasi Penelitian yang berada di Kota Medan Sumatera Utara. Lokasi Pengabdian Masyarakat dilaksanakan di Kantor Lurah seperti pada Gambar 2.2. berikut ini :

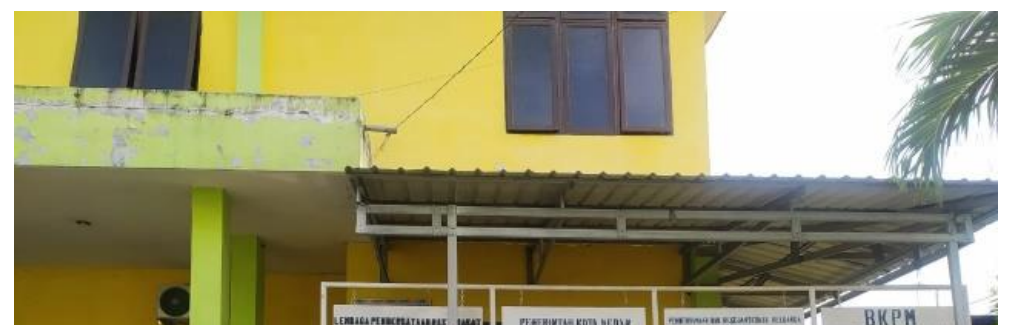


Gambar 2.2. Lokasi Pengabdian Masyarakat di Kelurahan Tegal Sari Mandala II Kecamatan Medan Denai Kota Medan

Gambar 2.2. menunjukkan lokasi dilaksanakannya sosialisasi dan pelatihan pembuatan hand sanitizer kepada masyarakat, yakni di Kantor Lurah Kelurahan Tegal Sari Mandala II Kecamatan Medan Denai Kota Medan

\subsection{Preparasi Bahan Baku}

Banah baku daun Eucalyptus citriodora dicuci bersih kemudian dipotong halus dan ditimbang sebanyak $10 \mathrm{Kg}$ kemudian disiapkan sebagai sampel.

\subsection{Ekstraksi}

Daun Eucalyptus citriodora yang telah halus kemudian dimasukkan ke dalam alat destilasi, kemudian ditambahkan air sebagai pelarut. Proses destilasi dilakukan pada Temperatur $275^{\circ} \mathrm{C}$ selama 4 Jam. Minyak Eucalyptus yang diperoleh kemudian ditampung untuk digunakan sebagai bahan baku Hand sanitizer.

\subsection{Pencampuran}

Proses pencampuran dilakukan secara manual dengan mempergunakan wadah dan pengaduk berbahan plastik. Untuk membuat Hand sanitizer sebanyak 1 Liter, dicampurkan Minyak Eucalyptus hasil destilasi sebanyak $10 \mathrm{ml}$, kemudian ditambahkan Alkohol sebesar $600 \mathrm{ml}$, kemudian glycerin $250 \mathrm{ml}$ dilanjutkan dengan $\mathrm{H}_{2} \mathrm{O}_{2}$ sebanyak $2 \mathrm{ml}$ dan dicukupkan dengan air sampai 1 L. Semua bahan diaduk selama 10 menit dan dibiarkan selama 1 malam agar kondisi stabil.

\subsection{Pengemasan}

Pengemasan Hand Sanitizer Alami yang dihasilkan dilakukan dengan menggunakan wadah botol plastik $100 \mathrm{ml}$.

\subsection{Sosialisasi}

Sosialisasi kepada masyarakat di sekitar dilaksanakan secara berkala selama 1 (satu) bulan. Masyarakat dilatih tentang pembuatan Hand sanitizer alami, kemudian diberikan pengetahuan 
tentang sifat dan kegunaan bahan, sumber bahan baku agar menghasilkan peluang baru masyarakat untuk menghasilkan pendapatan keluarga di Era New Normal ini.

\section{HASIL DAN PEMBAHASAN}

Di Era New Normal ini, tingkat kepedulian masyarakat terhadap kebersihan dan kesehatan semakin meningkat (Weiss and Murdoch 2020). Masyarakat sudah memulai kembali beraktivitas seperti ke kantor, belanja ke super market, sekolah, jalan-jalan ke mall, maupun sudah memulai aktivitas untuk berekreasi. Areal publik yang sudah mulai beroperasi serta keinginan masyarakat untuk keluar rumah setelah cukup lama hanya berada di rumah dapat menggerakan kembali perekonomian (Erni et al. 2020). Namun di sisi lain kegiatan ini dapat membuat penyebaran virus menjadi lebih cepat. Oleh karena itu, penerapan kebiasaan new normal dengan mematuhi protokol kesehatan tetap harus dijalankan. Salah satunya adalah sering menggunakan hand sanitizer. Pada Kegiatan ini Hand sanitizer yang digunakan adalah berbahan dasar daun Eucalyptus citriodora.

Beberapa sediaan hand sanitizer memiliki kandungan alkohol yang tinggi dapat menyebabkan kulit tangan kering dan jika dibiarkan dapat terjadi iritasi pada kulit. Untuk itu agar kulit tangan tetap lembab dan tidak kering selama saat menggunakan hand sanitizer, maka penggunaan bahan alami seperti 1,8 Sineol yang terdapat pada Daun Eucalyptus citriodora sangat membantu menetralisir agar tidak terjadi alergi dan dapat membunuh bakteri dan virus.

\subsection{Preparasi, ekstraksi dan Pembuatan Hand Sanitizer}

Proses preparasi dan ekstraksi senyawa aktif (1,8 Sineol) yang terdapat dalam Daun Eucalyptus citriodora dilakukan dalam rangka eksplorasi metode efektif dan mudah. PAda Kegiatan ini, metode destilasi yang digunakan adalah destilasi uap dimana terjadi perubahan titik didih pada Temperatur $275^{\circ} \mathrm{C}$. Rendemen yang dihasilkan adalah sebesar $0,5 \%$. Proses pembuatan Hand sanitizer dilanjutkan dengan bahan lain seperti alcohol, glycerin, $\mathrm{H}_{2} \mathrm{O}_{2}$ dan aquadest. Proses pencampuran dilaksanakan agar homogenitas dari produk terjaga dengan baik.

\subsection{Sosialisasi}

Sosialisasi dilaksanakan kepada masyarakat secara kontiniu dan berbasis masyarakat. Dalam hal ini, masyarakat diberikan pemahaman tentang kegunaan hand sanitizer, bahan baku yang digunakan, cara mengekstraksi, cara mencampur dan memasukkan ke dalam wadah. Kegiatan sosialisasi yang telah dilaksanakan dapat dilihat pada Gambar 3.1. berikut ini :
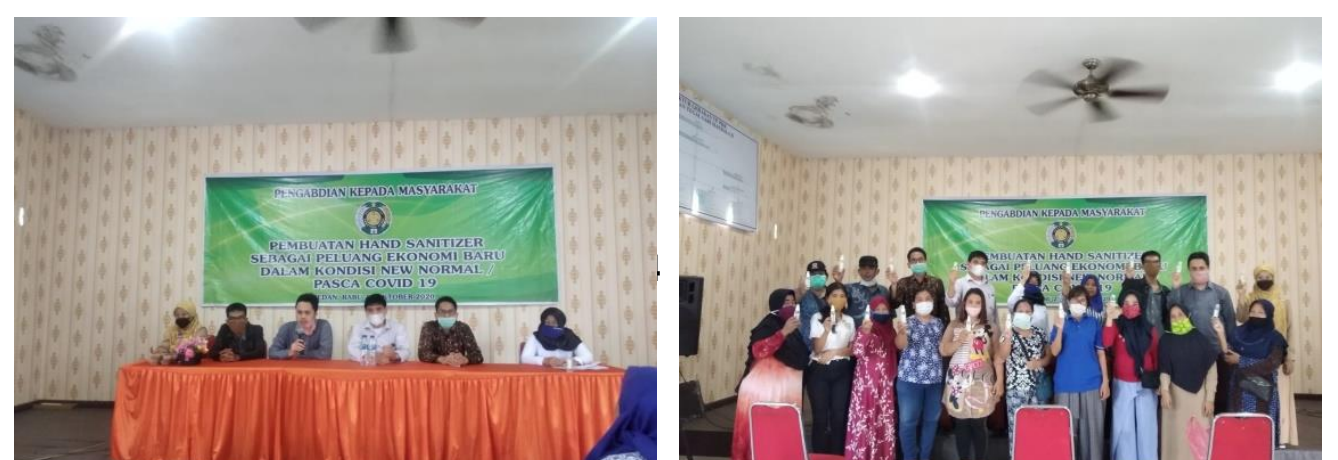
(a)

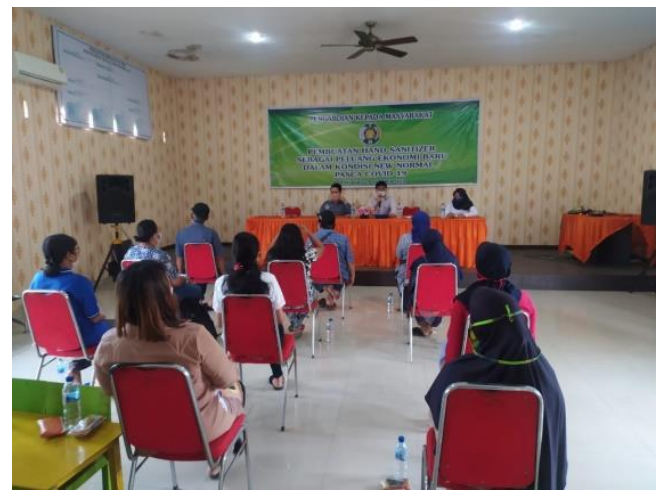

(c) (b)

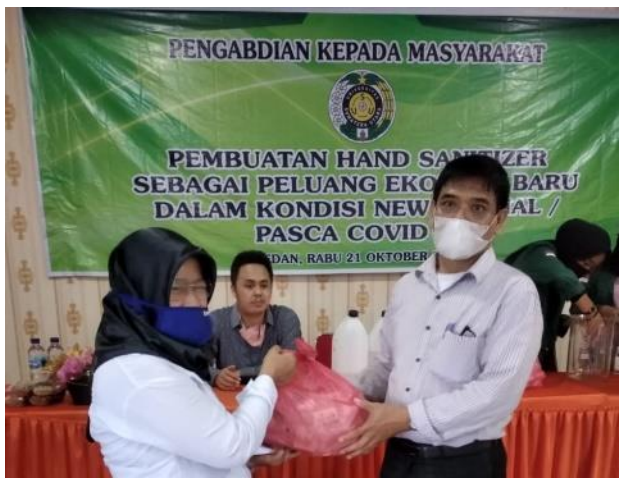

(d)

Gambar 3.1. Sosialisasi pembuatan Hand sanitizer kepada Masyarakat (a) Pengarahan dari Tim Pengabdian Masyarakat. (b) Pemberian produk Hand sanitizer kepada peserta pelatihan. (c) Sosialisasi kegiatan pelatihan. (d) Pemberian Produk Hand sanitizer kepada masyarakat di Sekitar melalui Lurah.

Selama Masa Pandemi Covid19, masyarakat kota Medan khususnya di Kelurahan Tegal Sari Mandala II Kecamatan Medan Denai telah kehilangan pekerjaan akibat industry dan berbagai usaha mengalami kerugian karena produk tidak laku dan masyarakat sulit mengakses produk yang ada karena harga yang mahal. Dalam hal ini Tim Pengabdian Masyarakat memberikan pelatihan pembuatan produk hand sanitizer agar produk yang dihasilkan dapat digunakan sendiri dan menjadi produk home industry yang dapat meningkatkan perekonomian keluarga. Penemuan potensi pekerjaan baru dilakukan melalui motivasi kepada masyarakat dan memberikan alternative sehingga akan menghasilkan peluang ekonomi baru dalam kondisi new normal/pasca covid19. Bagaimanapun kegiatan ini merupakan salah satu alternative dalam peningkatan ekonomi keluarga khususnya di Kelurahan Tegal Sari Mandala II Kecamatan Medan Denai Kota Medan.

\section{KESIMPULAN}

1. Hand sanitizer dari Tanaman Eucalyptus citriodora dapat dijadikan sebagai Peluang Ekonomi di Era New Normal.

2. Setelah dilakukan pelatihan dan soisalisi cara pembuatan Hand sanitizer, masyarakat memiliki kemampuan yang baik dalam pembuatan Hand sanitizer yang dapat diaplikasikan sebagai peluang usaha baru dalam menghasilkan pendapatan keluarga di Era Pandemi Covid19. 
M. Syafii, et.al Making Hand sanitizer from Eucalyptus citriodora plants

\section{UCAPAN TERIMAKASIH}

Penulis mengucapkan terima kasih kepada Rektor Universitas Sumatera Utara atas dana penelitian Pengabdian Masyarakat melalui Skema Dosen Wajib Mengabdi 2020.

\section{DAFTAR PUSTAKA}

Acharya, Shri Balakrishna et al. (2020). 1 Formulation, Evaluation and Antibacterial Efficiency of Water-Based Herbal.

Alfian, Z et al. (2019). "GC-MS Analysis of Chemical Contents and Physical Properties of Essential Oil of Eucalyptus Grandis from PT. Toba Pulp Lestari." Asian Journal of Chemistry 31(10): 2319-22.

Andre, Manfred Smieschek, Stollenwerk Patrick J, Thorsten Orlikowsky, and Mark Schoberer. (2016). "Evaluating Hand Disinfection with Alcohol-Based Hand Sanitizers Using Thermal Imaging." In 2nd Workshop on Fail Safety in Medical Cyber-Physical Systems, Wien 2016 Evaluating, , 174-81.

Dixit, A, P Pandey, R Mahajan, and Dhasmana Dc. (2014). "Alcohol Based Hand Sanitizers: Assurance and Apprehensions Revisited ." Research Journal of Pharmaceutical , Biological and Chemical Sciences 5(558): 558-63.

Erni, Risna et al. (2020). "Education of Making Natural Hand Sanitizers to the Community of Haulasi Village , North Central Timor Regency.” Abdimas Talenta 5(2): 144-49.

Fatmawati, Fenti. (2020). "Edukasi Penggunaan Hand Sanitizer dan Pembagian Hand Sanitizer disaat Pandemi Covid-19." Journal of Character Education Society 3(2): 432-38.

Ghasemian, M. (2018). "Journal of Fisheries \& Eucalyptus Camaldulensis Extract as a Preventive to the Vibriosis in Western White Shrimp ( Litopenaeus Vannamei ) in Bushehr Province." Journal of Fisheries \& Livestock Production 6(2): 2-6.

Han Roliadi, Dulsalam, Dian Anggraini. (2010). "Penentuan Daur Teknis Optimal Dan Faktor Eksploitasi Kayu Hutan Tanaman Jenis Eucalyptus Hbrid Sebagai Bahan Baku Pulp Kertas.” Jurnal Litbang Pertanian 1(1): 1-20.

hayat, aliya, and fizza munnawar. (2017). "Antibacterial Effectiveness of Commercially Available Hand antibacterial Effectiveness of commercially available hand." Int. J. Biol. Biotech. 13(3): 427-31.

He, Feng, Yu Deng, and Weina Li. (2020). “Coronavirus Disease 2019: What We Know ?” J Med Virol 1(March): 1-7.

Narang, Aryan. (2018). "Comparing the Effectiveness of Various Hand-Sanitizers against E . Coli." International Journal of Pharmaceutical Science and Research ISSN: 3(4): 16-18.

Niken, Eliza Arman, and Honesty Diana Morika. (2020). "Lawan Covid-19: Stikes Syedza Saintika Salurkan Hand Sanitizer Sebagai Wujud Pengabdian pada MasyarakaT." Jurnal Abdimas Saintika Jurnal Abdimas Saintika 2(1): 91-95.

Praveen, D, Ranadheer Chowdary, and Vijey Aanandhi M. (2020). "Janus Kinase Inhibitor Baricitinib Is Not an Ideal Option for Management of COVID-19." International Journal of Antimicrobial Agents 1(xxxx): 5-6.

Weiss, Paul, and David R Murdoch. (2020). "Covid-19: Towards Controlling of a Pandemic." doi 6736(20): 1015-18.

Xavier, Marilia B., Marcia M. R. Ferreira, Juarez A. S. Quaresma, and Arival C. de Brito. (2006). "Hand Sanitizer Alert." Emerging Infectious Diseases • 12(3): 527-29. 